DETERMINANTS OF TRUST IN SUPPLIER RELATIONS:

EVIDENCE FROM THE AUTOMOTIVE INDUSTRY

IN JAPAN AND THE UNITED STATES

Mari Sako

and

Susan Helper 



\title{
DETERMINANTS OF TRUST IN SUPPLIER RELATIONS: EVIDENCE FROM THE AUTOMOTIVE INDUSTRY IN JAPAN AND THE UNITED STATES
}

\author{
MARI SAKO \\ Industrial Relations Department \\ London School of Economics and Political Science \\ SUSAN HELPER \\ Department of Economics \\ Case Westem Reserve University
}

Forthcoming in the Journal of Economic Behavior and Organization

1996

\begin{abstract}
This study examines the determinants of inter-organisational trust by using survey data from just over 1000 suppliers in the automotive industry. We define trust and derive a model of its determinants from transaction cost economics, game theory and sociological exchange theory. Regression analysis results indicate that determinants of trust are different from determinants of opportunism. US-Japanese differences are found in three respects: (i) the way trust is conceptualised by suppliers is richer in Japan than in the US; (ii) the level of trust is higher in Japan than in the US; and (iii) the factors facilitating trust and those attenuating opportunism differ in the US and Japan.

JIL Classification Codes: L14, L22, L23, L62

Key Words: trust, opportunism, supplier relations, auto industry.

NOTE: Proofs and reprints to be sent to: Mari Sako, Industrial Relations Department, London School of Economics and Political Science, Houghton Street, London WC2A 2AE, UK.
\end{abstract}


The advantage to mankind of being able to trust one another penetrates into every crevice and cranny of human life.' (J S Mill 1891, p.68)

'Virtually every commercial transaction has within itself an element of trust, certainly any transaction conducted over a period of time. It can be plausibly argued that much of the economic backwardness in the world can be explained by the lack of mutual confidence.' (Arrow 1975, p.24)

\section{INTRODUCTION AND REVIEW OF LITERATURE}

Recent work on trust between business organizations focuses on the possibility of using it to enhance competitive advantage (Barney and Hansen 1994, Jarillo 1988, Mohr and Spekman 1994). In fact, an increasing number of studies exhort companies to build trust with their business partners (e.g. Dodgson 1993, SMMT \& DTI 1994). However, trust is sometimes understood to be a by-product of norms, embedded in social networks and rarely brought about through rational-instrumental means (Granovetter 1985). Even if trust could be cultivated intentionally, it is regarded as a scarce commodity which only a few can afford (Gambetta 1988, 224pp.). Before an explicit strategy of developing and maintaining trust can be considered feasible, the determinants of trust must be identified. This paper is a stepping stone towards developing a strategic framework for trust. It combines the strength of the economics discipline which has focused on how trust may be created deliberately, and that of the psychology discipline which has endeavored to develop a reliable survey technique for measuring trust. The empirical part of the paper is based on a large scale survey of automotive parts suppliers in the United States and Japan.

Inter-organisational trust may enhance organizational performance in a number of ways. For instance, trust enables a network of firms to adapt to unforeseen circumstances which are common in a world of risk and uncertainty, thus reducing transaction costs (Jarillo 1988). Also, trust is said to promote suppliers' willingness to invest in customer-specific and general assets (Dyer forthcoming). But while theoretical work abounds, empirical work on the link between trust and performance has been rare. In empirical work, as in theory, it is opportunism rather than trust which has attracted more attention (e.g. Anderson 1988). Moreover, opportunism or trust tend not to be measured directly; these features are instead assumed to be present in transactions with certain characteristics such as specific assets (Klein, Crawford, and Alchian 1978) or long-term trading (Gulati 1995). Therefore, we believe that the operationalization of trust is an important task. 
The central concept explored in this paper is mutual trust between a customer and a supplier organization. Trust is an expectation held by an agent that its trading partner will behave in a mutually acceptable manner (including an expectation that neither party will exploit the other's vulnerabilities). This expectation narrows the set of possible actions, thus reducing the uncertainty surrounding the partner's actions. In discussing the notion of mutual trust, however, we focus on situations in which each party can take alternative courses of action. Thus, predictability in behavior exists for different reasons arising from a 'freewill' choice when agents are confronted with different alternatives, not because of severe constraints which force them to stick to a single possible course of action. Sako $(1991,1992)$ used these different reasons to distinguish between three types of trust: 'contractual trust' (will the other party carry out its contractual agreements?), 'competence trust' (is the other party capable of doing what it says it will do?), and 'goodwill trust' (will the other party make an open-ended commitment to take initiatives for mutual benefit while refraining from unfair advantage taking?).

The study of inter-personal trust has a long history within the psychology discipline (e.g. Deutsch 1958; Rotter 1967; see Clark 1993 for a good literature survey). Much progress has been made in developing reliable attitudinal measures of trust (Cook and Wall 1980; Cook et al 1991). But in the context of business organizations, this focus on psychology is deficient. In particular, while psychologists tend to study inter-personal trust, business firms are concerned just as much with inter-organizational trust. It is the latter which might survive a breakdown of inter-personal relationships due to labor turnover or personality clash, and which provides the stability necessary for firms to pursue innovative and competitive activities. For this reason, the determinants of inter-personal and inter-organizational trust may well be different (Barney and Hansen 1994), although similar methods may be applied to analyze them (Smith, Carroll and Ashford 1995).

Recently, Williamson (1993) has objected to the increasingly popular notion of 'calculative trust' which is an assessment of the expected benefits and costs of cooperation. He called for the restriction of the usage of the term 'trust' to personal trust only, a situation in which Williamson assumes no monitoring occurs. Here, he appears to conflate the absence of continuous calculation with the absence of monitoring. In inter-organizational trust, as in some marriages and friendships, trust tends to be associated with periodic intense mutual observation (Sabel, 1992 \& 1994, Lorenz 1993). But this does not necessarily imply that all firms are always calculating benefits and costs of each action they take with respect to another firm. 
Despite Williamson's concerns, the concept of interorganizational trust is widely used in both the marketing and the strategy literature. For examples of empirical work see Zaheer and Venkatraman (1995), Parkhe (1993), Anderson and Weitz (1989), Morgan and Hunt (1994), Kumar, Sheer, and Steenkamp (1995), Ganesan (1994), and Cummings and Bromiley (1996). The scales used by these authors to measure trust meet conventional criteria of validity, such as internal consistency and face validity. In addition, Gulati (1995) finds that firms act as if they gain trust in each other over time; firms which have engaged in alliances with each other before are less likely to use equity, "since interfirm trust based on prior alliances reduces the imperative to use equity".

There is also a good deal of case-study evidence that interorganizational trust can survive the departure of the individuals who initially established the relationship. Ono, Adachi and Odaka (1988) describe the close ties that bind Toyota and its long-term suppliers. Eccles (1981) shows that participants in the US construction industry have repeated dealings with each other, dealings which are governed by trust rather than by legally-enforceable guarantees. Similar arrangements are also found in other areas, such as the "Third Italy" (Brusco 1986), the Japanese textile industry (Dore, 1983), and the Japanese electronics industy (Sako 1992).

In organizational studies, it has been common to focus on determinants of 'governance structures' or 'governance mechanisms' (such as markets vs hierarchies and intermediate modes including long-term contracts, joint ventures and other forms of alliances) (Heide and John 1990, Joskow 1988, Walker and Weber 1984). Trust or opportunism enter into some of these analyses as either one of the determinants of governance structures or a governance structure in itself. As an example of the former, trust is a social norm which lessens the need to use hierarchy to attenuate opportunism. Thus, the higher the general level of trust, the less need there is for vertical integration (Williamson 1985) or equity-holding (Gulati 1995). Here, trust tends to be conceptualised as a substitute for various governance mechanisms. Also, trust may be a society-wide norm or a norm which develops in dyadic relationships. As an example of the latter, 'governance by trust' is an informal control mechanism which enhances the effectiveness of transactions whether they take place in markets or within a hierarchy (Smitka 1991). This conceptualization introduces the possibility that trust may complement, rather than substitute for, hierarchy or market (Bradach and Eccles 1989, Smitka 1992). However, unlike equity holding or long-term written contracts, interorganizational trust as a form of governance remains ill-defined because it is less tangible and more informal. It has been noted that difficulties in defining the presence or absence of trust in a consistent manner have caused much misunderstanding both within and between disciplinary fields (Hosmer 1995). 
In economics, the interest in trust has come from a rather oblique angle, mainly from two theoretical perspectives, transaction cost economics and game theory. In transaction cost economics, opportunism (self-interest seeking with guile), rather than trust, has been a central concept. In designing organizations, the reliance on trust is seen to be too fragile as compared to devising safeguards against opportunism (Williamson 1985, p.64). Opportunistic behavior is said to be irresistable for parties encountering a cocktail of specific assets and uncertainty. Vertical integration or obligational contracting is put forward as an optimal 'governance structure' for attenuating such behavior (Williamson 1979). Attenuating opportunism, however, is not the same as attaining mutual trust, as will be shown in this paper.

In game theory, economists are interested in the evolution of cooperation. Even selfinterested agents will cooperate if they expect a positive pay-off from cooperation, a situation more likely with repeated encounters over an infinite or uncertain time horizon than in one-time transactions (Kreps 1990). However, cooperation cannot be equated with trust. This is because cooperation may emerge where no trust exists (Axelrod 1984). Also, trust as a subjective state of mind may not have a straightforward linear relationship to cooperation or trust as manifested in behavior (Kee and Knox 1970).

This paper is structured as follows. Section 2 develops a conceptual framework for defining trust and analyzing its determinants, by borrowing approaches from economic, sociological and psychological theories. This framework is used to develop a number of hypotheses. Section 3 reports the results of factor analysis used to create composite measures of trust, and regression analysis to test the hypotheses. Section 4 concludes by drawing theoretical and empirical implications of this study.

\section{CONCEPTUAL FRAMEWORK AND HYPOTHESES}

\subsection{Differentiating Trust and Opportunism}

In this paper, we conceptualize trust to be not a mere opposite of opportunism. This is due to a distinction we make among different types of trust, following Sako (1992). A precondition for trust of the contractual and goodwill types is the absence of opportunistic behavior. However, lack of opportunism is not a sufficient condition for goodwill trust. For example, a supplier that withholds a vital piece of technical information is acting opportunistically according to the goodwill trust definition but not in the strict contractual 
sense. This amounts to fulfilling the letter, but not the spirit, of the contract. Thus, there seems to be a hierarchy of trust, with fulfilling a minimal set of obligations constituting 'contractual trust', and honoring a broader set constituting 'goodwill trust'. A move from contractual trust to goodwill trust involves a gradual expansion in the congruence in beliefs about what is acceptable behavior. As one goes higher up the hierarchy, also, a looser form of reciprocity applies between the trading partners. Reciprocation may take a broader range of forms, and more time may elapse between the receipt of a favor and its return (Gouldner 1960).

Such reciprocity gives grounds for arguing that trust is a mutually self-enforcing set of expectations (Fox 1974, Zand 1972), so that it is not possible for a customer to continue to trust a supplier forever if the supplier starts to distrust the customer. In fact, a research design which allowed for asking two sides of a relationship whether each trusted the other gives evidence of such mutual trust (Currall and Judge forthcoming). Conceptually, however, the customer's trust of the supplier is separate from the supplier's trust of the customer. The empirical work in this paper is mainly about the supplier's trust of its customer.

\subsection{Conditions for Facilitating Trust and Attenuating Opportunism}

The main tasks of this paper are to operationalize the concept of trust, and to determine conditions which facilitate the creation and maintenance of trust. We believe that they constitute an important contribution to the study of determinants of governance structures.

The following hypotheses concern eight sets of factors which are thought to facilitate the creation and maintenance of trust between a customer and a supplier. Because the survey results reported in this paper focus on suppliers' trust of customers, the hypotheses will be in terms of this. Suppliers' perception of customer opportunism is hypothesized to be distinct from suppliers' trust of customers. Some conditions may prevent opportunism but do not necessarily foster trust, while other factors which enhance trust do not necessarily constitute a safeguard against opportunism. Moreover, we expect all the following hypotheses to be more significant in cases where customers are free to choose from alternative courses of action than when they are constrained, for example, by the lack of alternative suppliers in the marketplace.

Characteristics of the bilateral relationship are dealt with first before moving on to wider environmental and institutional conditions. 
Vertical integration and written contracts

Financial vertical integration is one solution given by transaction cost economists to attenuating the effects of supplier opportunism. In theory, integration gives the principal (the customer) better control and ability to monitor the agent's (the supplier's) behavior. In this sense, vertical integration is considered a substitute for 'governance by trust' (Smitka 1991); where there is control via integration, there is no need to rely on trust to coordinate activities. But in reality, vertical integration in itself has not assured better internal administrative coordination. For example, General Motors has not been able to persuade its internal divisions (and in particular its most formidable Fisher Body Division) to share cost information within the corporation (Helper 1991, pp.803-4). Transaction cost economics has focused on vertical integration attenuating the agent's (supplier's) opportunism. Therefore, it is not at all clear that the principal's own opportunism is attenuated by the principal's integration of the supplier.

The customer's ownership of suppliers may be interpreted by the latter as a form of credible commitment for long-term relationship, which in turn may lead to the absence of opportunistic behaviour by the customer (Williamson 1983). But vertical integration has not stopped the closure or selling off of component divisions by the Big Three in the US. Such recent US experience militate against the case for vertical integration attenuating customer opportunism. Thus, we may hypothesize that:-

H1A: Suppliers' trust of customers is not significantly affected by the degree to which they are vertically integrated by their customer, other things being equal.

H1B: Suppliers' perception of customer opportunism is not significantly affected by the degree to which they are vertically integrated by their customer, other things being equal.

Another governance structure is the long-term written contract. Long-term contracts may reduce the expectations of opportunistic behavior, but may not necessarily enhance trust. In fact where there is trust in a relationship, long-term written contracts are superfluous to the viability of the relationship. According to one strand of thinking (e.g. Kawashima 1967), appeal to legal authorities in itself introduces not only rigidity but suspicion into a relationship. However, some researchers (e.g. Lane and Backman 1996; Sitkin and Roth 1993) argue on the contrary that law may help strengthen the foundation upon which trust can grow under certain circumstances. While a general procedural legal framework may be conducive to the creation 
of trust, the substance of a business contract is typically left implicit or open-ended because of the benefit of flexibility such a contract affords in dealing with unforeseen circumstances. We can therefore hypothesize about opportunism but not about trust because contracts tend to be regarded as safeguards. Thus,

H1C: The longer the duration of written contracts, the lower the supplier's expectation of customer opportunism, other things being equal.

\section{Long-term trading and future expectations of customer commitment}

According to Axelrod (1984), it is the expectation of long-term commitment into the future -- what he calls 'enlarging the shadow of the future' -- rather than the record of longterm trading, which matters in making trading partners cooperate with each other (see also Heide and John 1990). Expectations of repeated transactions have led even litigious American business firms to rely on 'relational contracting' (Macaulay, 1963, Mcneil 1978). To the extent that trust is built by demonstrating trustworthiness over time, the historical duration of a relationship may also matter. That is, expectations of continuity may be induced by past association.

$\mathrm{H} 2 \mathrm{~A}$ : The longer the informal commitment made by the customer to continue trading with the supplier, the higher is the supplier's trust for its customer.

$\mathrm{H} 2 \mathrm{~B}$ : The longer the duration of past trading, the higher is the supplier's trust of its customer.

\section{Reciprocity in information exchange}

Sharing of information facilitates coordination between organizations. But disclosing proprietary or confidential information to the other party, that is acting as if one trusted the other, exposes one's vulnerability. In this situation, a two-way flow of information is essential

$\therefore$ ing and sustaining trust, which feeds on a loose form of reciprocity over time. Onenformation -- for example, a supplier being asked to provide information about its cess steps without the customer being more open about its future business plan -- 
is likely to be regarded with suspicion by the supplier as a sign of increased control.

Information asymmetry resulting from one-way flow of information also gives much scope for opportunistic behavior (Williamson 1975).

H3A: The more suppliers' disclosure of information to their customer is matched by the customer's provision of information to suppliers, the higher the supplier's trust for its customer.

H3B: The more suppliers are asked to provide information to their customer without the customer reciprocating by giving information to suppliers, the greater the supplier's perception of customer opportunism.

\section{Interdependence and asset specificity}

Axelrod (1984) wrote about the importance of perceived interdependence for cooperation to evolve. A deliberate strategy of locking oneself into a relationship, thus raising switching costs, may facilitate the creation and maintenance of trust. Investment in assets dedicated to the other party makes mutual commitment to the relationship credible, thus enhancing trust, particularly if both parties have equally good alternatives to turn to.

This proposition is in stark contrast to Williamson's earlier argument that in a situation of bilateral monopoly, 'it is in the interest of each party to seek terms most favorable to him, which encourages opportunistic representations and haggling' (Williamson 1975, p. 27). In contrast, in a situation with large numbers of bidders, "parties who attempt to secure gains by strategic posturing will find, at the contract renewal interval, that such behavior is nonviable.'

More recently, however, transactions cost theorists including Williamson (1983) himself, have argued that the establishment of 'credible commitments' or 'hostages' can bind the parties to trustworthy behavior even while it creates bilateral monopoly. Empirical support for this idea is provided by Anderson and Weitz (1992) and Heide and John (1990).

H4A: The greater the level of customer specific assets possessed by the supplier and the more difficult it is for the customer to switch away from the supplier, the higher the supplier's trust in its customer. 
H4B: The greater the level of customer-specific assets possessed by the supplier, the higher the supplier's perception of customer opportunism.

\section{Technical assistance}

One type of credible commitment that a customer can provide to a supplier is technical assistance, since the customer receives no return on its investment in training if it fires the supplier. In addition, the customer would have more trust in its suppliers' competence as a result. To the extent that the customer demonstrates knowledge and skills by providing technical assistance, it enhances suppliers' 'competence trust' of the customer. Over time, particularly if technical assistance is not fully paid for, suppliers would interpret it as a manifestation of commitment by the customer, and may become a basis for 'goodwill trust' (Sako 1992).

In the automobile industry, it is typically the customer which has greater market power in relation to its suppliers. Where there is such differential power between the customer and the supplier, the initiative taken by the more powerful partner - the customer - to commit to a relationship before receiving guarantees of trust from the weaker partner is conducive to the creation of trust. By contrast, the weaker partner may feel too vulnerable to make a commitment without immediate reciprocation from the stronger partner. A weaker partner is therefore more grateful for a show of commitment through technical assistance. At the same time, technical assistance provides no protection against opportunism, and therefore we cannot hypothesize about opportunism in this respect.

H5A: The more technical assistance is provided by the customer, the higher the supplier's trust in the customer.

H5B: The smaller the supplier is relative to the customer, the more trusting the supplier is for a given level of technical assistance.

\section{Uncertainty}

Unpredictability in business environments makes opportunism difficult to control because a firm, either customer or supplier, would find it difficult to write fully contingent 
contracts (Williamson 1975). However, at the same time, the greater the degree of environmental uncertainty, the greater the benefit from being able to trust a trading partner, because trust facilitates decision-making in unanticipated circumstances. Here, it may be useful to make a distinction between behavioral uncertainty (the source of which is the customer who may increase the degree of uncertainty by behaving in an unpredictable and/or opportunistic manner) and environmental uncertainty (the source of which is other than the customer, such as the cost of raw materials or the future trajectory of new technology). Environmental uncertainty creates a scope for opportunism when there are relation-specific investments (Walker and Weber 1984). However, behavioral uncertainty is reduced when opportunism is contained.

One source of uncertainty in the latter category arises from the technical complexity of the product being made by suppliers. The more complex the product, the harder it would be to write complete contingent contracts before orders are placed, and consequently the greater the need for trading partners to rely on trust. However, although the advantage of having trustworthy partners may be greater, the actual manifestation of trust for different levels of product complexity cannot be hypothesized.

H6A: The more uncertain the market and technology environments, and the higher the degree of asset specificity, the greater the level of customer opportunism.

National cultural values, business norms and past investment into trust

Trust between trading partners may vary not only with the attributes of transaction but also with the trading environment in which they are a part. Here, societal culture, politics, regulation, professionalisation, networks and corporate culture are said to be a relevant set of attributes in which a bilateral relationship may be embedded (Granovetter, 1985). For example, Smitka (1991) argues that 'governance by trust' is more prevalent in the Japanese than in the US automobile industry due to, among other things, the existence of suppliers' associations (kyoryokukai) in Japan and their absence in the USA. These associations enhance lateral communication among suppliers, and therefore act as an extra bulwark against customer opportunism (Sako 1996). Dore (1983) and Sako (1992) provide evidence that Japanese companies are more predisposed to trusting their trading partners than British companies. This is in part due to prevailing business norms, which are determined by societal-level cultural values. 
Societal norms may be self-reinforcing. Over time, a history of good experience with trusting behavior in Japan may have promoted the diffusion of trust. In fact, cultural norms such as trust can be 'the precipitate of history' (Dore 1987, p.91). For instance, Japanese suppliers in the automotive industry may trust their customers more today because they have had more customer commitment, more technical assistance, etc. over a much longer period of time than most US suppliers, and their trusting behavior has been honored by being given growing orders. In contrast, a typical (though more eloquent) US supplier executive asserted that their customer 'would steal a dime from a starving grandmother' (Helper 1991). Attempts by US companies to imitate the Japanese business norm are costly and difficult because the way in which a network of customer-supplier relations developed in Japan is path dependent.

Because of the extent to which norms of trustworthy behavior are embedded in a society, there is no reason to expect the same model of the determinants of trust to hold in each country (Dore 1983, Sako 1992). I For this reason, we control for national differences not only by using a dummy variable in the combined data set, but also by examining the determinants of trust in each country separately.

By extension, we may also hypothesize that because of this accumulated expectation of trust among Japanese companies, Japanese-owned suppliers in the USA are likely to trust their customers more than do other suppliers in the USA. Because of a reputation effect, even USowned suppliers may trust Japanese-owned customers more than the Big Three customers.

H7A: Suppliers in Japan tend to have a higher level of trust towards their customer than suppliers in the US.

H7B: In the US, Japanese-owned suppliers tend to entertain a higher level of trust towards their customer than do other suppliers.

H7C: In the US, suppliers to Japanese-owned automakers tend to entertain a higher level of trust towards their customer than do other suppliers.

\section{Customers' supplier management practices}

One caveat to the above generalisation about national culture and business norms is that suppliers' trust of customers may be customer-specific, and that within each country some 
customers may be perceived to be more trustworthy than others. For example, within Japan, the largest producer Toyota has a reputation for having been more consistent than other Japanese automakers in offering help (e.g. technical assistance on Total Quality, Just-in-Time, Value Analysis, etc.) which suppliers have found useful (Sako 1996). In the USA, despite a general trend towards longer-term relationships, General Motors has recently adopted a purchasing strategy which emphasizes the benefit of hard-nosed bargaining with little commitment to renew contracts (Helper 1994).

Over time, each customer may develop a reputation for particular procurement practices among the supplier community. The reputation may be for being receptive to suppliers' suggestions (rather than unwilling to consider them), or for providing help to reduce costs (rather than switch immediately to an alternative supplier) whenever a competitor offered a lower price or when material prices rose. These beliefs on the part of suppliers, whether they are based on actual past experience with their customer or hearsay, are hypothesized to be associated with high trust.

This hypothesis can also be seen as a test of whether the concept of inter-organizational trust makes sense. If it is true that trust can exist only between individuals, and that trustworthy individuals are randomly allocated across companies, then our data should reject the following hypothesis:

H8: The supplier's trust of customers within a country depends on the customer's supplier management practices.

\section{DATA ANALYSIS AND DISCUSSION}

The dataset used to test the above hypotheses were collected by the authors during 1993. For details on questionnaire design, the sampling framework and response rates, see Appendix A. The data is derived from responses from first-tier component suppliers in the automotive industry. Although single-industry studies may often lack generalizability, they have the advantage of controlling for sources of extraneous variation due to industry characteristics, environmental noise and the like. We solicited answers from one respondent per organization to make a large-scale international survey feasible (a total of $3000+$ questionnaires were sent out). 
Trust and opportunism concern subjective judgments and expectations. We relied on composite rather than single measures in order to reduce measurement errors. The measures of trust and opportunism were developed by surveying the academic literature in economics and psychology (e.g. Anderson 1988, Cook et al 1981). By contrast, most of the independent variables used for regression analysis, such as contract lengths and company size, are objective data and therefore are based on single-item measures.

\subsection{Different Types of Trust?}

Eight items used to measure trust and opportunism in the questionnaire are shown in Table 1. Each item is a five-point scale, ranging from strongly disagree (1) to strongly agree (5). The items were chosen to capture the notion of three types of trust and opportunism. For example, the concept of 'contractual trust' is operationalised by the statement 'We prefer to have everything spelt out in detail in our contract'. The concept of 'competence trust' is captured by a reversed statement 'The advice our customer gives us is not always helpful.' 'Goodwill trust' is operationalised by the statements 'We can rely on our customer to help us in ways not required by our agreement with them' and 'We can depend on our customer always to treat us fairly.' Other items were included to capture the notion of opportunism ('Given the chance, our customer might try to take unfair advantage of our business unit'), the notion of suspicion ('We feel that our customer often uses the information we give to check up on us rather than to solve problems.'), and distrust arising from lack of shared goals ('In dealing with this customer, we spend a lot of time haggling unproductively over such issues as prices and responsibility for problems.'). Lastly, although the survey was about suppliers' trust of customers, it attempted to gauge the extent of mutual trust by asking suppliers to assess their own trustworthiness ('Our business unit has a reputation for being more straightforward and open with our customer than are other suppliers').

When each item is examined separately, it is evident that Japanese suppliers tend to entertain a higher level of trust and a lower level of opportunism than US suppliers, except in their self-assessment of honesty and openness. Within the US, Japanese-owned suppliers and those which supply to Japanese customers tend to be more trusting and expect less opportunism from their customers. By contrast, suppliers to General Motors are significantly more suspicious of their customer. Within Japan, suppliers to Toyota are somewhat more trusting of their customer, according to a few of the items. 
Next, in order to examine if survey respondents differentiated between different types of trust, factor analysis was performed on the above items. Principal components analysis with varimax (orthogonal) rotation was used throughout. Of the eight items listed in Table 1, one concerning 'contractual trust' ('We prefer to have everything spelt out in detail in our contract') was dropped from the factor analysis because including it produced a factor loading of this item on all factors of below 0.2 in all cases. Table 2 shows that the results are substantially different in the US and Japanese surveys. In the USA, only one main factor emerged, which combines 6 items with a Cronbach's alpha of 0.811 . This factor may be labelled Distrust. The suppliers' self-assessment of their trustworthiness emerged as a separate factor. In Japan, however, the application of the same technique led to the emergence of three separate factors: Factor 1 (combining 4 items with a Cronbach's alpha of 0.726 ) called Customer Opportunism, Factor 2 (combining 2 items with a Cronbach's alpha of 0.599) called Goodwill Trust, and one item as a separate indicator of Competence Trust. 2 Next, the US and Japanese surveys were combined to perform factor analysis on the overall data. As shown in Table 2, one main factor, Distrust, which is the same as the US-only factor of Distrust, was identified, with a Cronbach's alpha of 0.816 .

Insert Table 2 about here

Thus, it seems from these results that as compared to US suppliers, Japanese suppliers distinguish among different types of trust. Moreover, as the Goodwill Trust Factor in the Japanese data indicates, reciprocity appears to be more embedded in the Japanese conceptualisation of trust than the US counterpart. In the Japanese data, opportunism and trust are not mere opposites; if they were, only one factor should have emerged from the above analysis. (See Deutsch 1958 \& 1960 who argues that trust and suspicion are not mere opposites.) By contrast, in the US, generalized distrust appears to prevail, possibly because distrust is self-perpetuating; distrust in one area (e.g. contractual) may induce distrust in another area (e.g. competence) due to the lack of information necessary in order to assess the source of misconduct. 


\subsection{Conditions for Facilitating Trust and Attenuating Opportunism}

How different are the factors which attenuate opportunism from those factors which enhance trust? Moreover, are there any differences in the facilitating conditions for trust in Japan and the USA?

The eight sets of hypotheses in the previous section were tested using ordinary least squares regression, with Distrust, Customer Opportunism and Goodwill Trust as alternative dependent variables. ${ }^{3}$ The independent variables are explained in detail in Appendix B. As the correlation matrices in the appendix show, there is no problem with multicollinearity. Note that coefficients of the regression equations shown in the subsequent Tables are standardized (i.e. all variables were standardized with mean zero and standard deviation one before regressions were run).

First, the US and Japanese datasets are combined to test the eight sets of hypotheses. Next, we focus our analysis on the question of whether determinants of trust are different from those of opportunism. We also test for a meta-hypothesis that more independent variables are significant in determining trust and opportunism in a 'freewill' than in a 'constrained' situation. Lastly, we deal with the Japanese and US datasets separately to test the hypothesis that the structural models of trust and opportunism are different in the two countries.

\section{Overall Results}

An overall multivariate regression analysis was conducted in order to test the relative importance of the eight sets of hypotheses. For each hypothesis, a set of relevant independent variables were regressed against the dependent variable, DISTRUST. Note that DISTRUST is a generalized form which conflates some notion of customer opportunism and the absence of trust. As shown in Table 3, the model fits the data reasonably well, with an adjusted $R^{2}$ of $41 \%$ which is excellent by the standards of cross-sectional research. All the hypotheses were sustained except for $\mathrm{H} 4$ (asset specificity and interdependence). Below is a brief summary of the regression results for each hypothesis.

Insert Table 3 about here 
H1: As predicted, vertical integration (OWNER) does not have a significant effect on the level of distrust. There was also weak, yet significant, result that longer contract length (CONTRACT) increases distrust, contrary to the prediction (see later for an explanation).

H2: As predicted, the longer suppliers expect their customer's commitment (COMMIT) to last, the lower the degree of distrust. But the duration of trading to date (TRADING) does not have a separate effect on distrust.

H3: The act of customers providing information to suppliers (CUSTINFO) in itself reduces distrust. However, the gap between suppliers' information to their customers and customers' information to suppliers (INFODIF) has an independent impact. As predicted, the more suppliers are asked to provide information to customers without reciprocation, the higher the level of suppliers' distrust in customers.

H4: A high switching cost on the part of customers (CUSWICH) does not affect distrust significantly. The degree of asset specificity on the part of the supplier (ATSPEC) does not have a significant impact, nor does the extent of interpdendence (INTDEP) between the customer and the supplier.

H5: As predicted, the more technical assistance (TECHG) is provided by the customer, the lower the supplier's distrust. However, the size of the supplier relative to the customer (COMPSIZE) had no significant effect on the level of distrust.

H6: Uncertainty (UNCERT) has a highly significant effect on increasing suppliers' distrust of customers. But neither uncertainty and asset specificity combined (TCE) nor the technical complex of the product exchanged (COMPLEX) has a significant impact on distrust.

H7: In order to examine the differential impact of ownership and location, a set of dummy variables were constructed with the US-owned suppliers with US customers located in the US as the base-line reference group. First, as the coefficient on the dummy variable, JAPJAPJ, indicates, the location of suppliers is highly significant: suppliers located in Japan exhibit a much lower level of distrust than those in the US. Within the US, suppliers which traded with Japanese automakers (USJAP and JAPJAPU) distrust them less, whether the suppliers themselves were Japanese-owned or US-owned. At the same time, Japanese-owned suppliers with US customers (JAPUS) entertained a level of distrust which was not significantly different from US-owned suppliers with US customers. Evidently, the nationality of 
ownership of customers matters more than the nationality of ownership of suppliers. Even after taking account of ownership and location, we found that US suppliers considered General Motors to be particularly distrustful.

H8: As predicted, suppliers' expectations about customers' supplier management practices had an impact on distrust. The survey asked suppliers about possible customer reactions in different hypothetical situations. In particular, suppliers' expectations that their suggestions would be welcomed without reservation and that benefits arising from the suggestions would be shared (SUGGEST) were associated with low distrust. Also, if a competitor offered a lower price for a product of equal quality, the customer practice of helping suppliers to match competitor's efforts (rather than swich to the competitor) (HELP) was associated with less distrust. Lastly, in the event that a materials supplier raised its prices, the customer practice of providing significant help to reduce costs and of allowing full or partial pass-through of the supplier's cost increases (rather than holding the supplier to its original price) (PASS) was not found to affect distrust significantly in the multiple regression analysis.

Insert Table 3 about here

\section{Differences in the Determinants of Trust and Opportunism}

Table 3 also shows separate regressions for Customer Opportunism and Goodwill Trust. As predicted, the determinants of trust and opportunism are not the same. In particular, the customer's provision of technical assistance to suppliers, interpretted as 'credible commitment' and a 'gift', enhances trust but does not function as a safeguard against opportunism. A type of information asymmetry -- suppliers providing much more information to customers than customers provide suppliers -- increases customer opportunism but does not affect goodwill trust adversely.

One way of exploring this issue of different determinants for trust and opportunism further is to distinguish between trustworthy customer behavior when a 'freewill' choice exists and the same trustworthy customer behavior which is however predictable due to contraints put upon the customer. In other words, only if customers can behave in many different ways would the notion of trust become interesting, and it is the determinants of trust in such unconstrained circumstances that are of interest here. We hypothesize that when customers are free rather than contrained or 'enslaved', more of the variations in suppliers' trust in customers can be explained by the independent variables. ${ }^{4}$ 
Our sample can be divided into subsamples, one with 'constrained' customers and the other with 'freewill' customers using the CUSWICH variable, measuring the number of months it would take the customer to replace the supplier with another supplier. Since the median month was 8 months, those with more than 8 months were classified as 'constrained' ( $41 \%$ of the total sample), and those with 8 months or less as 'free' ( $59 \%$ of the total sample). 5 Table 4 shows the results of regressions of GOODWILL TRUST and CUSTOMER OPPORTUNISM using these subsamples.

\section{Insert Table 4 about here}

Customers' provision of information to suppliers (CUSTINFO) and technical assistance (TECHG) stand out as two variables which are significant in determining trust when customers are 'free' but not when they are 'constrained'. This implies that when customers have different alternatives (including behaving distrustfully), the provision of information and technical assistance signals their commitment to behave in a trustworthy manner. When customers are constrained, information provision and technical assistance do not matter in creating suppliers' trust.

With respect to customer opportunism, the distinction between 'constrained' and 'free' situations illustrates the following two points which are noteworthy. First, as expected, many more safeguards against opportunism matter in the 'free' than in the 'constrained' situation. In particular, the minimisation of information asymmetry (INFODIF) and technical assistance (TECHG) are all significant in reducing customer opportunism in the 'free' subsample but not in the 'contrained' subsample. Thus, these credible commitments are worth making only if customers find it relatively easy to replace their existing suppliers quickly. Second, consistent with transaction cost theory, the combination of uncertainty and asset specificity leads suppliers to expect customers to behave opportunistically in the 'free' situation but not in the 'constrained' situation.

\section{Differences between Japan and the US}

Thus far, we have assumed that there are no US-Japanese differences in the determinants of trust and opportunism, other than those which can be captured by country- 
specific dummy variables. However, as mentioned in the discussion of the hypothesis $\mathrm{H} 7$ on national differences, we will now examine the possibility that determinants of trust and opportunism may be different between the US and Japan.

One standard approach to exploring whether the structural model of trust and opportunism is different between the US and Japan is to apply Chow tests (Johnston 1972, p.2192-207; Kennedy 1992, pp.108-9 \& 224). First, in order to test whether the US and Japanese datasets are poolable per se, the Chow test was applied to regressions with Distrust, Goodwill Trust and Customer Opportunism as alternative dependent variables. The test was significant in all three cases, with $\mathrm{F}(18,814)=5.83$ significant at $0.1 \%$ in the case of Distrust, $F(17,812)=1.66$ sigificant at $5 \%$ in the case of Goodwill Trust, and $F(17,816)=6.48$ sigificant at $0.1 \%$ in the case of Customer Opportunism. These results open up the possibility that the two national samples have distinctly different structural models.

In order to further explore this possibility, we examine separate regressions for the two countries. The results are shown in Tables 5. Columns 1 and 2 are the regression results for the Japanese data only, and the dependent variables are Goodwill Trust and Customer Opportunism, the two factors identified through factor analysis for the Japanese data. Columns 3 and 4 show the regression results for the US data, using the same Goodwill Trust and Customer Opportunism factors as dependent variables. What Column 3 shows is the conditions for enhancing trust in the US, had the same concept of goodwill trust as in Japan existed in the US. Similarly, Column 4 shows the conditions for attenuating customer opportunism if the same concept of customer opportunism as in Japan existed in the US. Only significant differences are reported below.

Insert Table 5 about here

(a) US-Japanese differences in the determinants of opportunism

The three aspects of long-termism have different impacts in Japan and the US. Column 2 of Table 5 shows that in Japan, the results are as expected. The duration of written contracts has no significant impact on Customer Opportunism because in the Japanese automotive industry, there tend not to be product-specific contracts, and the framework contract is typically renewed annually. Japanese customers therefore have not used contract length to make 
credible commitments for long-term trading. Instead, suppliers appear to base their expectations of future customer commitment on the history of long-term trading to date (TRADING).

By contrast, in the US, all the three variables of long-termism are significant, and the results for two out of the three variables are counter-intuitive. A longer duration of written contract is associated with a higher degree of Customer Opportunism. Moreover, the longer the history of trading to date (TRADING), the higher the level of opportunism. At the same time informal commitment (COMMIT) reduces opportunism. What appears to be happening in the USA is that suppliers with only a recent record of trading to date are given longer duration contracts than suppliers with a long history of trading with the same customer; the median contract length was 3 years for those with a record of supplying the customer for 4 years or less, as compared to one year for those with a record of supplying the customer for over 40 years. This contract duration is used by suppliers as a basis for projecting future customer commitment. Either, written contracts are not attenuating opportunistic behavior in the USA, contrary to transaction cost theory, or longer duration contracts are implemented in response to rampant opportunism. The cross-sectional nature of the dataset at hand cannot distinguish between the two possibilities. But it appears that given the past adversarial nature of relations in the US, long-term suppliers have had more experience of opportunism than have newer suppliers. Thus, long-term trading or repeated games are not sufficient to bring about trust in relationships (cf. Axelrod 1984, Gulati 1995).

\section{(b) US-Japanese differences in the determinants of trust}

Comparing Columns 1 an 3 in Table 5, it is evident that technical assistance (TECHG) is highly significant in enhancing trust in Japan but not in the US. Similar notions of customer help and expectations of cost sharing (HELP, PASS) create trust but again in Japan only.

In Japan, but not in the US, longer written contracts (CONTRACT) are associated with lower goodwill trust. This lends support to the notion that contracts breed and institutionalise suspicion. In other words, in Japan, while written contracts are not used to contain customer opportunism, they undermine goodwill trust. 6

\section{(c) Within-Japan differences in the determinants of trust and opportunism}

There are also other differences in the determinants of trust and those of opportunism within Japan where after all the two were regarded as distinct and not as mere opposites. 
First, greater information asymmetry (with the supplier asked to provide information without much reciprocation from the customer) (INFODIF) is found to increase opportunism as expected. In other words, if customers provide as much information to suppliers as suppliers do customers, the resulting ability of the suppliers to monitor customer behaviour leads to a reduction in customer opportunism. But INFODIF is also found to enhance trust. This counter-intuitive result may be picking up a mixture of factors; for one, the provision of information in itself is not sufficient to generate trust because it is the ways in which information is used (or abused) which matters. Also, suppliers may be willing to provide much information because of the goodwill trust which exists in the relationship.

Second, technical assistance by customers to suppliers significantly enhances trust in Japan, while its effect on dampening customer opportunism is not significant. Thus, there is evidence that this form of commitment made by customers, and the loose reciprocity which results from it, enhances trust but is deficient as a safeguard against customer opportunism.

\section{CONCLUSIONS}

The following main conclusions can be drawn from this study.

First, the conceptualisation of trust and opportunism was found to be different for the US and the Japanese suppliers, with the latter group demonstrating a greater capacity to distinguish among different types of trust. Because of this distinction, Japanese suppliers also conceptualised trust and opportunism not to be mere opposites.

Second, the surveys provided empirical support for the eight sets of hypotheses advanced in the paper. The conditions which facilitated the creation and sustenance of trust -and the containing of opportunism -- were found to include long-term commitment, information exchange, technical assistance, and customer reputation. Vertical integration was found not to have a significant effect on attenuating customer opportunism in the multivariate analysis. Thus, equity holding of suppliers by customers gives rise to varying levels of opportunism or trust depending on other supplier management techniques (such as information sharing, supplier suggestions and technical assistance) which are practiced in specific relationships. 
Third, Japanese suppliers were more tristing than US suppliers, even after taking account of these universal facilitating conditions. Within the US, having Japanese customers, but not the Japanese ownership of the suppliers themselves, had an impact on reducing distrust. Also General Motors continues to be perceived as a distrustful customer in all regressions. This indicates that even with all the usual safeguards against opportunism, GM has not been successful in convincing its suppliers that its commitments are credible.

Fourth, the US-Japanese differences lie not only in the conceptualisation of trust and the different levels of trust, but also in the determinants of trust and opportunism. In particular, the length of past trading to date and the length of written contracts were associated with greater opportunism in the US. The US automotive experience has historically been negative and this bias in expectations is carried forward to current practices. This is a worrying phenomenon because future expectations are often extrapolated from the past. This may be a reason why customers' informal commitment into the future has to be backed up by long-term written contracts for the commitment to be credible in the US. By contrast, written contracts were found to be an irrelevant governance mechanism in Japan in so far as its impact on opportunism was concerned. Contracts, however, was associated with lower goodwill trust in Japan, lending support to the view that they institionalize suspicion.

Fifth, this study found that the determinants of trust and those of opportunism are different. The survey data provides some evidence for this especially in Japan where trust and opportunism were found to be distinct concepts. In particular, as expected, technical assistance by customers is important for enhancing goodwill trust but not as a safeguard against customer opportunism.

Lastly, trust and opportunism are valid concepts only in situations where actors can choose from alternative courses of action. This study gives support to this notion. We find in particular that customers' provision of information to suppliers and technical assistance are significant in enhancing trust and attenuating customer opportunism only in cases where customers are 'free', but not when they are 'constrained' by market structure or technology. In other words, customers can be made to behave in a predictably trustworthy or nonopportunistic manner if they cannot replace their existing suppliers easily, regardless of other factors. It is when easily accessible alternative suppliers exist that suppliers give careful consideration to safeguards against opportunism and enhancers of trust. 


\section{ACKNOWLEDGMENT}

The authors acknowledge the funding support of the International Motor Vehicle Program (IMVP) at MIT which made this study possible. We also wish to express our gratitude to Pat Coburn for his computing expertise. We benefitted from helpful comments from Patricia Clifford, Ronald Dore, Jeff Dyer, Marvin Lieberman, Edward Lorenz, Riccardo Peccei and Michael Smitka.

\section{NOTES}

1. For example, in our field research, we found that US firms considered it untrustworthy for a customer to ask for a price reduction on an existing product, and considered it quite acceptable to win a contract through a low bid and then ask for a price increase later. In contrast, Japanese suppliers were used to reducing prices on their products; their customers considered it untrustworthy to ask for a price increase.

2. Factor analysis was also conducted by excluding the item on suppliers' self-assessment of their trustworthiness ('Our business unit has a reputation for being more straightforward and open with our customer than are other suppliers.'). A single factor emerged for the US sample, but two distinct factors were identified in the Japanese sample. This reinforces the evidence that US and Japanese suppliers conceptualise trust differently.

3. OLS and ordered probit regressions were also run using single item measures rather than composite measures derived from factor analysis. Similar results (with respect to signs and significance of independent variables) were obtained as between Customer Opportunism and the measure "Given the change, our customer might take unfair advantage of our business unit', and between Goodwill Trust and the measure 'We can rely on our customer to help us in ways not required by our agreement with them.'

4. Thanks to an anonymous referee for suggesting this distinction.

5. Just to make sure that neither of the subsamples consisted predominantly of US or Japanese suppliers, it was checked that $40.4 \%$ of the US sample and $42.5 \%$ of the Japanese sample are in the 'constrained' subsample.

6. These results in the US-Japanese differences are also underpinned by the dummy variable variant of the Chow test (Kennedy 1992, p.224). The latter shows that the differences between the US and Japanese datasets lie in the dummy intercept and the slope coefficients for CONTRACT, TECHG, and HELP. 
Data were collected by the authors during 1993 from 675 first-tier automotive component suppliers in the US and 472 first-tier suppliers in Japan, according to the following procedure.

Questionnaire Design

A questionnaire was developed in English and Japanese, in order to enquire into a broad range of questions concerning the nature of suppliers' relationship with their customers, the vehicle manufacturers. Because many companies supply their customers with several different types of products, and their relationships with their customers differ by product, we made a decision to ask respondents to answer the questionnaire for their most important customer regarding one product which was typical of their company's output and with which they were familiar.

Many of the questions were taken from an earlier survey undertaken by Helper in North America in 1989 (Helper 1991) and a short questionnaire on trust and opportunism administered by Sako in the electronics industry in Japan and Britain in 1988-9 (Sako 1992). In particular, the measures of trust and opportunism were developed by surveying the academic literature in economics and psychology (e.g. Anderson 1988, Cook et al 1981). We took the view more common in psychology than in economics that creating composite measures of trust and opportunism would reduce measurement error, as compared to using a single measure. Thus, the questionnaire adopted a number of scales, each reflecting different types of trust and opportunism.

\section{Pilotting the Questionnaire}

Next, the draft questionnaire was sequentially piloted at a handful of supplier companies in both the USA and Japan during 1992. As a result, improvements were made to the clarity of questions and the ease of answering them. Much attention was paid to the phrasing of questions in a vocabulary familiar to managers, and to the consistency of meaning in the English and Japanese languages. For instance we asked several people to translate some 
questions from English to Japanese and others to translate them back from Japanese into English. The process of piloting and revision took around nine months.

Sampling Framework

The sample chosen for the North American questionnaire was every automotive supplier and automaker component division named in the Elm Guide to Automotive Sourcing (available from Elm, Inc. in East Lansing, Michigan). This guide lists the major first-tier suppliers (both domestic and foreign-owned) to manufacturers of cars and light trucks in the United States and Canada.

In Japan, the sample consisted of all members of the Japan Auto Parts Industries Association (JAPIA), all automotive suppliers named in Nihon no Jidosha Buhin Kogyo 1992/1993 (Japanese Automotive Parts Industry) (published by Auto Trade Journal Co. Inc. and JAPIA, Tokyo, 1992), and the component divisions of vehicle manufacturers. This publication lists all the first-tier suppliers (both domestic and foreign-owned) to the eleven manufacturers of cars and trucks in Japan.

The target respondent in the US was the divisional director of sales and marketing, and the divisional business manager or director of strategic planning in the case of components divisions of vehicle manufacturers. Since they commonly take a lead in interfacing with customers, they were deemed the most knowledgeable informants about customers' procurement practices. Similarly in Japan, the questionnaire was sent to the Director of Sales and Marketing at independent firms. For member companies of JAPLA, the survey was sent to the main contacts named by JAPIA, many of whom were either chief executives or marketing directors. JAMA (Japan Auto Manufacturers Association) took responsibility to identify the respondents for automaker components divisions.

\section{Response Rates}

The questionnaires were sent out in spring 1993 in the US and summer 1993 in Japan. The responses were far above the norm for business surveys. It was $55 \%$ in North America and $30 \%$ in Japan (45\% among JAPIA members), after taking into account those firms which were unreachable (mail sent to them was returned undelivered), and those which were not eligible to answer the survey (they were not first-tier automotive suppliers, or they specialised 
in supplying for heavy truck and buses). The respondents had a wealth of experience, and were thus the single individual able to answer all of our questions for the customer/product paire they chose. US respondents averaged more than 18 years in the automobile industry and more than 11 years with their company. Japanese respondents had worked for 22 years on average at their company.

We tested for non-response bias in several ways. First, we compared the characteristics of those who returned the survey to those of the entire population. On the characteristics for which data was available (size and location) no significant differences were found. The survey respondents were also divided into 2 groups based on response date. The hypothesis was that those who responded only after the second follow-up mailing might have more in common with those who did not respond at all than those who responded early. This test showed no significant differences for early and late responders on any of the measures used in this paper. (We judged statistical significance in both cases using a $10 \%$ cutoff). 


\section{Appendix B Explanations of Independent Variables}

This appendix provides the survey question and explains any manipulation made subsequently to create each independent variable.

VARIABLE NAMES

OWNER

'Please describe the ownership of your business unit.

Independent of automaker

$100 \%$ subsidiary of an automaker

Partially owned by an automaker

(percentage of automaker ownership)'

Ranges from 0 (for 'independent of automaker) to 100.

CONTRACT 'What is the length of your written contract or purchase order with this customer for this product?' (in years)

TRADING

'Approximately how long has your firm sold products in this product line to this customer?

1 year 2 years 3 years 4 years $5-10$ years $11-19$ years $20-40$ years 41-60 years over 60 years'

The mid-point of each interval was used; thus the variable takes the values of $1,2,3,4,7.5,15,30,50.5$, and 75 .

COMMIT

'For how long do you think there is a high probability that your business unit will be supplying this or similar item to your customer?' (in years)

SUPINFO

'What types of information does your business unit provide to your customer about the process you use to maker the product you listed above? (Please check all that apply.)

- Detailed breakdown of process steps

- Cost of each process steps

- Financial information not publicly available

- Production scheduling information

- Type of equipment used

- Your sources of supply

- Detailed information regarding materials you use' 
The seven information items were given one point each if checked, and were added.

CUSTINFO

'Does your customer provide you with any of the following types of information? (Please check all that apply.)

- Warranty or other data from final consumers

- Financial information not publicly available

- Information on how your product is used in their process'

The information items were given one point each if checked, and added.

INFODIF

TECHG

COMPSIZE

CUSWICH

ATSPEC

\section{SUFINFO - CUSTINFO}

'Over the last four years, what sorts of technical assistance have you received from your customer? (Please check all that apply, and indicate whether 'provided for zero or nominal charge' or 'provided for a fee')

- Provided personnel who visited supplier site to aid in implementing improved procedures

- Arranged for training of your personnel at their site

- Provided personnel who worked two weeks or more on your shopfloor to improve your process'

Given a weight of 2 if 'provided for zero or nominal charge' and a weight of 1 if 'provided for a fee', and summed over the three items.

'What is the approximate total number of employees at your business unit in 1992?'

'Please estimate the number of months it would take your customer to replace your business unit with another supplier. Consider the time required to locate, qualify, train, make investments, test, and develop a working relationship with another firm. Please exclude legal considerations such as the existence of long-term contracts.

$\begin{array}{llllll}0 & 1-3 & 4-12 & 13-24 & 25-48 & 48+\end{array}$

The mid-point of each interval was used. The variable therefore takes a value of $0,2,8,18.5,36.5$ and 72 .

'If you were to stop getting these orders from this customer, approximately how much of your investment for this product in plant, 
equipment, and training would you be unlikely to find alternative uses for and have to write off?

$10 \%$ or less $\quad 11-33 \% \quad 34-66 \% \quad 67-89 \% \quad 90-100 \%$ '

Again, the mid-point of each interval was used $(5,22,50,78$, and 95).

Each supplier is, however, diversified in sectors outside the car industry to a varying degree. In order to derive the extent of asset specificity which is company wide, the above proportions were multiplied by the percent of the supplier's sales which end up as original equipment for cars or light trucks.

INTDEP

UNCERT

TCE

COMPLEX

SUGGEST

\section{CUSWICH * ATSPEC}

'In the production of this product, how much certainty is there regarding the following factors? (A 1-5 Likert scale (1=fairly certain;

$5=$ completely unpredictable))

- Customer's production schedule 2 weeks ahead

- Customer's production schedule 1 year ahead

- Customer's final product specifications before Job 1

- Customer's final product specifications after Job l'

(Job 1 is the first mass production batch, after pre-production test runs)

- The supplier's production costs over 4 years

- Production technology for this product over 4 years

The scores for the six items were summed.

\section{UNCERT * ATSPEC}

'Please estimate the technical complexity involved in manufacturing this product' Used a 1-5 scale ( $1=$ fairly simple; 5=highly complex).

'Suppose your business unit has an idea that would allow you to reduce your costs, but would require your customer to make a slight modification in its procedures. How would your customer react? (Please check all that apply.)'

A dummy with 1 if 'Customer eagerly solicits such suggestions' and 'Customer would adopt the suggestion and would not seek to capture most of the savings', 0 otherwise. 
HELP

'How would your customer react if one of your competitors offered a lower price for a product of equal quality?

A dummy with 1 if 'Help you match competitors' efforts', but not 'Switch at end of contract', nor 'swich as soon as technically feasible'

PASS

'How would your customer react if your material suppliers raised their prices?'

A dummy with 1 if 'Provide significant help for your business unit to reduce costs', but not 'Hold you to your original price', 0 otherwise. This is meant to capture the notion of customer help and sharing of costs.

USJAP A dummy with 1 for US-owned suppliers with a Japanese customer in the US, 0 otherwise.

JAPUS

A dummy with 1 for Japanese-owned suppliers with a US customer in the US, 0 otherwise.

JAPJAPU A dummy with 1 for Japanese-owned suppliers with a Japanese customer in the US, 0 otherwise.

JAPJAPJ A dummy with 1 for Japanese suppliers in Japan, 0 otherwise.

GM A dummy with 1 for US suppliers supplying to General Motors.

TOYOTAJ A dummy with 1 for Japanese suppliers supplying to Toyota in Japan. 
DESCRIPTTVE STATISTICS AND CORRELATION MATRIX 


\section{REFERENCES}

Anderson, E. 1988, Transaction costs as determinants of opportunism in integrated and independent sales force, Journal of Economic Behavior and Organization 9, 247-264.

Anderson, E. and B. Weitz. 1989, Determinants of continuity in conventional industrial channel dyads, Marketing Science, 8, 310-323.

Arrow, K.J. 1975, Gifts and exchanges, in E.S. Phelps ed., Altruism, morality and economic theory_ (Russell Sage Foundation, New York).

Axelrod, R. 1984. Evolution of cooperation (Basic Books, New York).

Barney, Jay B. and Mark H. Hansen 1994, Trustworthiness as a source of competitive advantage, Strategic Management Joumal 7, 175-190.

Bradach, J. L. and R.G. Eccles 1989, Price, authority and trust: From ideal types to plural forms, Annual Review of Sociology 15, 96-118.

Brusco, S. 1986. Small firms and industrial districts: the experience of Italy, in D. Keeble and F. Weever, eds., New Firms and Regional Development. (Croom Helm, London).

Clark, K. 1989, Project scope and project performance: The effect of parts strategy and supplier involvement on product development, Management Science 35, 1237-1263.

Clark, Murray C. 1993, Interpersonal trust in the coal mining industry: A facet analysis. Unpublished PhD thesis, Manchester Business School, Manchester.

Cook, J. and T. Wall 1980, New work attitude measures of trust, organizational commitment and personal need non-fulfilment, Journal of Occupational Psychology 53, 39-52.

Cook, J. D. et al. 1981. The experience of work: A compendium and review of 249 measures and their use. (Academic Press, Orlando).

Cummings, L.L. and Bromiley, P. 1996, The organizational trust inventory (OTI): development and validation, in Kramer, R.M. and Tyler, T.R. (eds.) Trust in organizations: frontiers of theory and research. (Sage, London).

Currall, S. C. and T.A. Judge Forthcoming, Measuring trust between organizational boundary role persons, Organizational Behavior and Human Decision Processes.

Deutsch, M. 1958, Trust and suspicion, Journal of Conflict Resolution 2(4), 265-279.

Dodgson, M. 1993, Learning, trust and technological collaboration, Human Relations 46(1).

Dore, R. 1983. Goodwill and the spirit of market capitalism, British Journal of Sociology 34, 459-482.

Dore, R. 1987. Taking Japan seriously (Stanford University Press, Stanford).

Dyer, J. Forthcoming. Does governance matter? Keiretsu alliances and asset specificity as source of Japanese competitive advantage, Organization Science. 
Eccles, R. 1981. The quasifirm in the construction industry, Joumal of Economic Behavior and Organization, 2, 335-357.

Fox, A. 1973. Beyond contract : Work, power and trust relations. (Faber and Faber, London).

Gambetta, D. ed., 1988, Trust: making and breaking cooperative relations. (Basil Blackwell, Oxford).

Ganesan, S. 1994, Determinants of long-term orientation in buyer-seller relationships, Journal of Marketing, 58, 1-19.

Goulder, A. 1960, The norm of reciprocity: A preliminary statement, American Sociological Review 25(2); 161-177.

Granovetter, M. 1985, Economic action and social structure: The problem of embeddedness American Journal of Sociology 91, 481-510.

Gulati, R. 1995, Does familiarity breed trust? The implications of repeated ties for contractual choice in alliances, Academy of Management Journal 38, 85-112.

Heide, J. B. and G. John 1990, Alliances in industrial purchasing: The determinants of joint action in buyer-supplier relationship, Journal of Marketing Research 27, 24-36.

Helper, S. 1991, Strategy and irreversibility in supplier relations: The case of the US automobile industry, Business History Review 65.

Helper, S. 1994, Three steps forward, two steps back in automotive supplier relations, Technovation 14(10), 1-8.

Helper, S. and M. Sako 1995, Supplier relations in the auto industry in Japan and the USA: Are they converging? Sloan Management Review Spring: 77-84.

Hosmer, L. T. 1995, Trust: The connecting link between organizational theory and philosophical ethics, Academy of Management Review 20(2), 379-403.

Joskow, P.L. 1988, Asset specificity and the structure of vertical relationships: Empirical evidence, Journal of Law, Economics and Organization 4(1), 95-118.

Jarillo, J.C. 1988, On strategic networks, Strategic Management Journal 9, 31-41.

Johnston, J. 1972. Econometric methods. (McGraw-Hill, New York)

Kawashima, T. 1967. Nihonhin no hoishiki (Legal Consciousness of the Japanese). (Iwanami shoten, Tokyo).

Kee, H. W. and R. E. Knox 1970, Conceptual and methodological considerations in the study of trust and suspicion, Journal of Conflict Resolution 14(3), 357-366.

Kennedy, Peter 1992, A guide to econometrics. (Blackwell, Oxford)

Klein, B., R.A. Crawford, and A. A. Alchian 1978, Vertical integration, appropriable rents, and the competitive contracting process, Journal of Law and Economics 21(2), 297-326.

Kumar, N., L. Scheer, and J. Steenkamp , 1995. The effects of perceived interdependence on dealer attitudes, Journal of Marketing Research, 32, 348-356. 
Lane, C. and R. Backman 1996, The social construction of trust: supplier relations in Britain and Germany, Organization Studies 17(3), 365-395.

Lorenz, E. H. 1993, Flexible production systems and the social construction of trust, Politics and Society 21(3), 307-324.

Macaulay, S. 1963, Non-contractual relations in business: Prelimianry study, American Sociological Review 28(2), 55-67.

Macneil, I.R. 1974, Contracts: Adjustment of long-term economic relationship under classical, neo-classical, and relational contract law, Northwestern University Law Review 72, 584-906.

Mill, J.S. 1891. Principles of political economy. (Longmans, London).

Mohr, J. and R. Spekman 1994, Characteristics of partnership success: Partnership attributes, communication behavior, and conflict resolution techniques, Strategic Management Journal 15, $135-152$

Morgan, R. and S. Hunt. 1994, The commitment-trust theory of relationship marketing, Journal of Marketing, 58, 20-38.

Odaka, K., K. Ono, and F. Adachi, 1988. The Automobile industry in Japan: a study of ancillary firm development. (Oxford University Press, Oxford).

Parkhe, A. 1993, Strategic allicance structuringg: a game theoretic and transaction cost examination of interfirm cooperation, Academy of Management Journal, 36,794-829.

Ring, P.S. and A.H. Van de Ven 1994, Developmental processes of cooperative interorganizational relationships, Academy of Management Review 19: 90-118.

Rotter, J. B. 1967, A new scale for the measurement of interpersonal trust, Journal of Personality 35, 651-665.

SMMT \& DTI 1994, A review of the relationships between vehicle manufacturers and suppliers. (Society of Motor Manufacturers and Traders and the UK Department of Trade and Industry, London).

Sabel, C. F. 1992. Studied trust: building new forms of co-operation in a volatile economy, in Pyke, F. and W. Sengenberger eds., Industrial districts and local economic regeneration. (International Institute for Labour Studies, Geneva).

Sabel, C.F. 1994. Leaming by monitoring: the institutions of economic development, in Smelser, N.J. and Swedberg, R. (eds.) The handbook of economic sociology. (Princeton University Press, Princeton, N.J.).

Sako, M. 1991. The role of "trust" in Japanese buyer-supplier relationships, Ricerche Economiche XIV: $449-474$.

Sako, M. 1992. Prices, quality and trust: inter-firm relations in Britain and Japan. (Cambridge University Press, Cambridge).

Sako, M. 1996. Suppliers' associations in the Japanese automobile industry: Collective action for technology diffusion. Cambridge Journal of Economics. 
Sitkin, S. B. and Roth, N.L. 1993, Explaining the limited effectiveness of legalistic 'remedies' for trust/distrust, Organization Science 4 (3), 356-92.

Smith, K. G., S. J. Carroll, and S.J. Ashford 1995. Intera- and interorganizational cooperation: Toward a research agenda, Academy of Management Journal 39, 7-23.

Smitka, M. 1991, Competitive ties: Subcontracting in the Japanese automotive industry. New (Columbia University Press, York).

Smitka, M. 1992, Contracting without contracts. in Sitkin, S.B. and Bies, R.J. Eds. The legalistic organisation. (London: Sage).

Walker, G. and D. Weber 1984, A transaction cost approach to make-or-buy decisions, Administrative Science Quarterly 29, 373-391.

Williamson, O. E. 1975. Markets and hierarchies. (The Free Press, New York).

Williamson, O. E. 1979, Transaction-cost economics: the governance of contractual relations, Journal of Law and Economics 22, 3-61.

Williamson, O.E. 1983, Credible commitments: using hostages to support exchange, American Economic Review, 73,519-40.

Williamson, O. E. 1985. The economic institutions of capitalism. (The Free Press, New York).

Williamson, O. E. 1993, Calculativeness, trust, and economic organization, Journal of Law and Economics 36, 453-486.

Zaheer, A. and N. Venkatraman. 1995. Relational governance as an interorganizational strategy: an empirical test of the tole of trust in economic exchange, Strategic Management Journal, 16, 373-392.

Zand, D.E. 1972, Trust and managerial problem solving, Administrative Science Quarterly 17, 229-239. 
TABLE 1: Differences in Trust and Opportunism in Japan and the USA (Percent agreeing)

\begin{tabular}{|c|c|c|c|c|c|c|c|c|c|c|}
\hline & \multicolumn{2}{|c|}{$\begin{array}{l}\text { Japan vs USA } \\
\mathrm{N}=472 ; \mathrm{N}=675\end{array}$} & \multicolumn{2}{|c|}{$\begin{array}{l}\text { IN JAPAN } \\
\text { TOYOTA } \\
\text { (N=103) }\end{array}$} & \multicolumn{2}{|c|}{$\begin{array}{l}\text { IN USA } \\
\text { JAPCUST } \\
\text { (N=92) }\end{array}$} & \multicolumn{2}{|l|}{$\begin{array}{l}\text { IN USA } \\
\text { JAPOWN } \\
(\mathrm{N}=75)\end{array}$} & \multicolumn{2}{|l|}{$\begin{array}{l}\text { IN USA } \\
\text { GM } \\
(\mathrm{N}=242)\end{array}$} \\
\hline & JAPAN & USA & No & Yes & No & Yes & No & Yes & No & Yes \\
\hline $\begin{array}{l}\text { We feel that our customer often uses the information we give to } \\
\text { check up on us, rather than to solve problems. }\end{array}$ & $1.72 * * *$ & 2.67 & 1.75 & 1.62 & 2.74 & $2.23^{* * *}$ & 2.70 & $2.48 \dagger$ & 2.55 & $2.89 * *$ \\
\hline The advice our customer gives us is not always helpful. & $2.51^{* * *}$ & 3.37 & 2.61 & $2.17 * * *$ & 3.42 & $3.06^{*}$ & 3.40 & 3.16 & 3.25 & $3.59 * *$ \\
\hline We prefer to have everything spelt out in detail in our contract. & $3.08 * *$ & 3.74 & 3.15 & $2.84^{* *}$ & 3.81 & $3.24 * * *$ & 3.79 & $3.37 * * *$ & 3.68 & $3.85^{*}$ \\
\hline $\begin{array}{l}\text { Gjven the chance, our customer might try to take unfair advantage of } \\
\text { our business unit. }\end{array}$ & $1.90^{* * *}$ & 2.87 & 1.97 & $1.69 \dagger$ & 2.97 & $2.19^{* * * *}$ & 2.92 & $2.52^{* *}$ & 2.63 & $3.30^{* * *}$ \\
\hline $\begin{array}{l}\text { In dealing with this customer, we spend a lot of time haggling } \\
\text { unproductively over such issues as prices and responsibility for } \\
\text { problems. }\end{array}$ & $2.05^{* * *}$ & 2.74 & 2.13 & $1.79 * * *$ & 2.80 & $2.28 * * *$ & 2.78 & $2.44^{* *}$ & 2,58 & $3.02 * *$ \\
\hline $\begin{array}{l}\text { We can rely on our customer to help us in ways not required by our } \\
\text { agreement with them. }\end{array}$ & $3.17^{*}$ & 3.02 & 3.13 & $3.33 \dagger$ & 2.92 & $3.73 * * *$ & 2.96 & $3.46^{* * *}$ & 3.26 & $2.60^{* *}$ \\
\hline $\begin{array}{l}\text { Our business unit has a reputation for being more straightforward } \\
\text { and open with our customer than are other suppliers. }\end{array}$ & $3.49 * * *$ & 3.73 & 3.47 & 3.56 & 3.73 & 3.75 & 3.72 & 3.87 & 3.74 & 3.73 \\
\hline We can depend on our customer always to treat us fairly. & $3.91 * * *$ & 2.97 & 3.85 & $4.11 * *$ & 2.84 & $3.85^{* * *}$ & 2.88 & $3.54^{* * *}$ & 3.33 & $2.31^{* *}$ \\
\hline
\end{tabular}

Note: The figures show the average scores for responses on a $1-5$ scale (5=strongly agree; $4=$ agree; $3=$ neither agree nor disagree; $2=$ disagree; $1=$ strongly disagree). T-test is significant a *** $\mathrm{p}<.001 \quad * * \mathrm{p}<.01 \quad{ }^{*} \mathrm{p}<.05 \quad+\mathrm{p}<.10$ 
TABLE 2 : Factor Analysis of Trust Scales in Japan and the US

\begin{tabular}{|c|c|c|c|c|c|c|c|}
\hline & $\begin{array}{l}\text { USA } \\
(\mathrm{N}=630)\end{array}$ & & $\begin{array}{l}\text { JAPAN } \\
(\mathrm{N}=445)\end{array}$ & & & $\begin{array}{l}\text { USA \& } \\
\text { JAPAN }\end{array}$ & $(\mathrm{N}=1073)$ \\
\hline & $\begin{array}{l}\text { FACTOR } 1 \\
\text { Distrust }\end{array}$ & FCTR 2 & $\begin{array}{l}\text { FCTR 1 } \\
\text { Customer } \\
\text { Opportun- } \\
\text { ism }\end{array}$ & $\begin{array}{l}\text { FCTR 2 } \\
\text { Goodwill } \\
\text { Trust }\end{array}$ & $\begin{array}{l}\text { FCTR } 3 \\
\text { Compet- } \\
\text { ence Trust }\end{array}$ & $\begin{array}{l}\text { FCTR } 1 \\
\text { Distrust }\end{array}$ & FCTR 2 \\
\hline $\begin{array}{l}\text { We feel that our customer often uses the } \\
\text { information we give to check up on us rather } \\
\text { than to solve problems. }\end{array}$ & 0.60503 & 0.12658 & 0.37895 & -0.04483 & 0.31211 & 0.64480 & 0.02903 \\
\hline $\begin{array}{l}\text { The advice our customer gives us is not } \\
\text { always helpful. }\end{array}$ & 0.39588 & -0.02763 & 0.23556 & -0.20108 & 0.28699 & 0.45445 & -0.08273 \\
\hline $\begin{array}{l}\text { Given the chance, our customer might try to } \\
\text { take unfair advantage of our business unit. }\end{array}$ & 0.81950 & 0.00883 & 0.71744 & -0.10321 & 0.07664 & 0.82441 & -0.08989 \\
\hline $\begin{array}{l}\text { In dealing with this customer, we spend a lot } \\
\text { of time haggling unproductively over such } \\
\text { issues as prices and responsibility for } \\
\text { problems. }\end{array}$ & 0.68365 & 0.07649 & 0.71289 & -0.07189 & 0.06598 & 0.71701 & -0.06391 \\
\hline $\begin{array}{l}\text { We can rely on our customer to help us in } \\
\text { ways not required by our agreement with } \\
\text { them. }\end{array}$ & -0.61820 & 0.16127 & -0.13264 & 0.56331 & 0.04835 & -0.41088 & 0.40548 \\
\hline $\begin{array}{l}\text { Our business unit has a reputation for being } \\
\text { more straightforward and open with our } \\
\text { customer than are other suppliers. }\end{array}$ & -0.14842 & 0.17452 & -0.12673 & 0.59547 & -0.11507 & -0.05079 & 0.36242 \\
\hline $\begin{array}{l}\text { We can depend on our customer always to } \\
\text { treat us fairly. }\end{array}$ & -0.74042 & 0.15150 & -0.56046 & 0.35477 & -0.03758 & -0.71806 & 0.25394 \\
\hline Cronbach's alpha coefficient & 0.811 & & 0.726 & 0.599 & & 0.816 & \\
\hline
\end{tabular}


TABLE 3

Regression Coefficients on Distrust, Customer Opportunism and Goodwill Trust

\begin{tabular}{|c|c|c|c|}
\hline & Distrust & $\begin{array}{l}\text { Customer } \\
\text { Opportunism }\end{array}$ & Goodwill Trust \\
\hline $\begin{array}{l}\text { OWNER } \\
\text { CONTRACT }\end{array}$ & $\begin{array}{c}-0.017 \\
0.049 \dagger\end{array}$ & $\begin{array}{l}-0.017 \\
0.054 \dagger\end{array}$ & $\begin{array}{c}0.034 \\
-0.026\end{array}$ \\
\hline $\begin{array}{l}\text { TRADING } \\
\text { COMMIT }\end{array}$ & $\begin{array}{l}0.014 \\
-0.053 \dagger\end{array}$ & $\begin{array}{l}0.018 \\
-0.064 * * *\end{array}$ & $\begin{array}{l}0.002 \\
0.044\end{array}$ \\
\hline $\begin{array}{l}\text { CUSTINFO } \\
\text { NNFODIF }\end{array}$ & $\begin{array}{l}-0.054 \dagger \\
0.095^{* * *}\end{array}$ & $\begin{array}{l}-0.029 \\
0.089 * *\end{array}$ & $\begin{array}{r}0.051 \\
-0.002\end{array}$ \\
\hline $\begin{array}{l}\text { CUSWICH } \\
\text { ATSPEC } \\
\text { INTDEP }\end{array}$ & $\begin{array}{l}-0.009 \\
-0.061 \\
-0.033\end{array}$ & $\begin{array}{l}-0.051 \dagger \\
-0.157 \\
----\end{array}$ & $\begin{array}{c}-0.004 \\
-0.008 \\
0.075\end{array}$ \\
\hline $\begin{array}{l}\text { TECHG } \\
\text { COMPSIZE }\end{array}$ & $\begin{array}{l}-0.100^{* * *} \\
0.038\end{array}$ & $\begin{array}{r}-0.035 \\
0.059\end{array}$ & $\begin{array}{l}0.110^{* *} \\
-0.021\end{array}$ \\
\hline $\begin{array}{l}\text { UNCERT } \\
\text { TCE } \\
\text { COMPLEX }\end{array}$ & $\begin{array}{l}0.232 * * * \\
0.098 \\
-0.024\end{array}$ & $\begin{array}{l}0.191^{* * *} \\
0.222^{*} \\
-0.005\end{array}$ & $\begin{array}{l}-0.124 * * * \\
-0.007\end{array}$ \\
\hline $\begin{array}{l}\text { USJAP } \\
\text { JAPUS } \\
\text { JAPJAPU } \\
\text { JAPJAPJ }\end{array}$ & $\begin{array}{l}-0.044 \dagger \\
0.021 \\
-0.055^{*} \\
-0.230\end{array}$ & $\begin{array}{l}-0.042 \\
0.001 \\
-0.042 \\
-0.202 * * *\end{array}$ & $\begin{array}{c}0.041 \\
0.021 \\
0.074^{*} \\
-0.062\end{array}$ \\
\hline $\begin{array}{l}\text { SUGGEST } \\
\text { HELP } \\
\text { PASS }\end{array}$ & $\begin{array}{l}-0.175^{* * *} \\
-0.100^{* * *} \\
-0.030\end{array}$ & $\begin{array}{l}-0.136^{* * *} \\
-0.086 * * * \\
-0.006\end{array}$ & $\begin{array}{l}0.103^{* *} \\
0.071^{*} \\
0.139^{* * *}\end{array}$ \\
\hline $\begin{array}{l}\text { GM } \\
\text { TOYOTAJ }\end{array}$ & $\begin{array}{l}0.166^{* * *} \\
0.046\end{array}$ & $\begin{array}{l}0.138^{* * *} \\
-0.028\end{array}$ & $\begin{array}{l}-0.154 * * * \\
0.037\end{array}$ \\
\hline $\begin{array}{l}\text { Adjusted R2 } \\
\mathrm{N}\end{array}$ & $\begin{array}{l}0.41 \\
850\end{array}$ & $\begin{array}{l}0.31 \\
844\end{array}$ & $\begin{array}{l}0.14 \\
845\end{array}$ \\
\hline$* * * p<.001$ & ${ }^{*} \mathrm{p}<<.01$ & $<.05$ & $\dagger \mathrm{p}<.10$ \\
\hline
\end{tabular}

N.B. The dependent variable for Customer Opportunism is: 'Given the chance, our customer might try to take unfair advantage of our business unit.'

The dependent variable for Goodwill Trust is: 'We can rely on our customer to help us in ways not required by our agreement with them.'

The table reports OLS regression results. Ordered probit analysis for Customer Opportunism and Goodwill Trust shows that the identical set of independent variables as for OLS are significant.

INTDEP $=$ CUSWICH * ATSPEC

TCE $=$ UNCERT $*$ ATSPEC 
TABLE 4

Regression Coefficients on Goodwill Trust and Customer Opportunism in Constrained and Free Conditions

\begin{tabular}{|c|c|c|c|c|}
\hline & $\begin{array}{l}\text { Goodwill } \\
\text { Constrained }\end{array}$ & $\begin{array}{l}\text { Trust } \\
\text { Free }\end{array}$ & $\begin{array}{l}\text { Customer } \\
\text { Constrained }\end{array}$ & $\begin{array}{l}\text { Opportunism } \\
\text { Free }\end{array}$ \\
\hline $\begin{array}{l}\text { OWNER } \\
\text { CONTRACT }\end{array}$ & $\begin{array}{r}0.036 \\
-0.082\end{array}$ & $\begin{array}{l}0.011 \\
0.035\end{array}$ & $\begin{array}{c}-0.079 \\
0.090 \dagger\end{array}$ & $\begin{array}{r}-0.044 \\
0.029\end{array}$ \\
\hline $\begin{array}{l}\text { TRADING } \\
\text { COMMIT }\end{array}$ & $\begin{array}{r}-0.027 \\
0.063\end{array}$ & $\begin{array}{r}-0.023 \\
0.016\end{array}$ & $\begin{array}{l}-0.097 \dagger \\
-0.072\end{array}$ & $\begin{array}{l}-0.090^{*} \\
-0.048\end{array}$ \\
\hline $\begin{array}{l}\text { CUSTINFO } \\
\text { INFODIF }\end{array}$ & $\begin{array}{r}-0.003 \\
0.026\end{array}$ & $\begin{array}{l}0.073 \dagger \\
0.037\end{array}$ & $\begin{array}{r}-0.012 \\
0.051\end{array}$ & $\begin{array}{l}-0.036 \\
0.128 * *\end{array}$ \\
\hline $\begin{array}{l}\text { CUSWICH } \\
\text { ATSPEC } \\
\text { INTDEP }\end{array}$ & $\begin{array}{l}-0.109 \\
-0.061 \\
0.189\end{array}$ & $\begin{array}{r}0.051 \\
0.040 \\
-0.040\end{array}$ & $\begin{array}{c}-0.039 \\
0.014 \\
\ldots \ldots\end{array}$ & $\begin{array}{l}-0.026 \\
-0.350^{*} \\
-\end{array}$ \\
\hline $\begin{array}{l}\text { TECHG } \\
\text { COMPSIZZE }\end{array}$ & $\begin{array}{l}0.080 \\
0.007\end{array}$ & $\begin{array}{l}0.140^{* *} \\
-0.039\end{array}$ & $\begin{array}{l}0.027 \\
0.053\end{array}$ & $\begin{array}{c}-0.077 \dagger \\
0.067+\end{array}$ \\
\hline $\begin{array}{l}\text { UNCERT } \\
\text { TCE } \\
\text { COMPLEX }\end{array}$ & \begin{tabular}{l}
$-0.136 * *$ \\
\hdashline 0.077
\end{tabular} & $\begin{array}{l}-0.101^{*} \\
-0.067\end{array}$ & $\begin{array}{l}0.282 * * * \\
-0.114 \\
0.035\end{array}$ & $\begin{array}{l}0.150^{* *} \\
0.415^{* *} \\
-0.022\end{array}$ \\
\hline $\begin{array}{l}\text { USJAP } \\
\text { JAPUS } \\
\text { JAPJAPU } \\
\text { JAPJAPJ }\end{array}$ & $\begin{array}{l}0.033 \\
-0.040 \\
0.158^{* * *} \\
-0.017\end{array}$ & $\begin{array}{r}0.038 \\
0.010 \\
-0.020 \\
-0.078\end{array}$ & $\begin{array}{l}-0.099^{*} \\
-0.059 \\
-0.101^{*} \\
-0.121 \dagger\end{array}$ & $\begin{array}{c}-0.002 \\
0.052 \\
0.035 \\
-0.238 * * *\end{array}$ \\
\hline $\begin{array}{l}\text { SUGGEST } \\
\text { HEIP } \\
\text { PASS }\end{array}$ & $\begin{array}{l}-0.041 \\
0.018 \\
0.179 * * *\end{array}$ & $\begin{array}{l}0.127^{* *} \\
0.144^{* * *} \\
0.118^{* *}\end{array}$ & $\begin{array}{l}-0.208 * * * \\
-0.078 \dagger \\
0.044\end{array}$ & $\begin{array}{l}-0.072 \dagger \\
-0.108 * * \\
-0.029\end{array}$ \\
\hline $\begin{array}{l}\text { GM } \\
\text { TOYOTAJ }\end{array}$ & $\begin{array}{l}-0.206^{* * *} \\
0.005\end{array}$ & $\begin{array}{c}-0.129 * \\
0.070\end{array}$ & $\begin{array}{l}0.160^{* *} \\
-0.035\end{array}$ & $\begin{array}{l}0.130 * * \\
-0.032\end{array}$ \\
\hline $\begin{array}{l}\text { Adjusted } R^{2} \\
N\end{array}$ & $\begin{array}{l}0.14 \\
343\end{array}$ & $\begin{array}{l}0.13 \\
502\end{array}$ & $\begin{array}{l}0.33 \\
343\end{array}$ & $\begin{array}{l}0.31 \\
501\end{array}$ \\
\hline
\end{tabular}

N.B.

'Constrained' if CUSWICH > 8; 'Free' otherwise.

Goodwill Trust: 'We can rely on our customer to help us in ways not required by our agreement with them.'

Customer Opportunism: 'Given the chance, our customer might try to take unfair advantage of our business unit.'

Ordered probit for the last two columns led to the same set of independent variables being significant in each regression. 


\section{TABLE 5}

Regression Coefficients on Customer Opportunism and Goodwill Trust in the US and Japan Separately

\begin{tabular}{|c|c|c|c|c|}
\hline & $\begin{array}{l}\text { JAPAN } \\
\text { Goodwill } \\
\text { Trust }\end{array}$ & $\begin{array}{l}\text { JAPAN } \\
\text { Customer } \\
\text { Opportunism }\end{array}$ & $\begin{array}{l}\text { USA } \\
\text { Goodwill } \\
\text { Trust }\end{array}$ & $\begin{array}{l}\text { USA } \\
\text { Customer } \\
\text { Opportunism }\end{array}$ \\
\hline $\begin{array}{l}\text { OWNER } \\
\text { CONTRACT }\end{array}$ & $\begin{array}{c}0.063 \\
-0.088 \dagger\end{array}$ & $\begin{array}{l}0.004 \\
-0.011\end{array}$ & $\begin{array}{l}-0.001 \\
-0.019\end{array}$ & $\begin{array}{l}-0.047 \\
0.098^{*}\end{array}$ \\
\hline $\begin{array}{l}\text { TRADING } \\
\text { COMMTT }\end{array}$ & $\begin{array}{r}-0.030 \\
0.060\end{array}$ & $\begin{array}{l}-0.098 * \\
-0.041\end{array}$ & $\begin{array}{l}0.040 \\
0.008\end{array}$ & $\begin{array}{c}0.098^{*} \\
-0.093^{*}\end{array}$ \\
\hline $\begin{array}{l}\text { CUSTINFO } \\
\text { INFODIF }\end{array}$ & $\begin{array}{l}0.061 \\
0.092 \dagger\end{array}$ & $\begin{array}{l}-0.069 \\
0.168^{* * *}\end{array}$ & $\begin{array}{l}0.074 \\
0.050\end{array}$ & $\begin{array}{l}0.0001 \\
0.138^{* * *}\end{array}$ \\
\hline $\begin{array}{l}\text { CUSWICH } \\
\text { ATSPEC } \\
\text { INTDEP }\end{array}$ & $\begin{array}{l}0.074 \\
0.052 \\
0.034\end{array}$ & $\begin{array}{l}-0.020 \\
-0.228 \\
---\end{array}$ & $\begin{array}{r}0.028 \\
-0.094 \\
0.024\end{array}$ & $\begin{array}{l}-0.011 \\
-0.090 \\
---\end{array}$ \\
\hline $\begin{array}{l}\text { TECHG } \\
\text { COMPSIZE }\end{array}$ & $\begin{array}{l}0.128^{* *} \\
-0.065\end{array}$ & $\begin{array}{c}-0.059 \\
0.061\end{array}$ & $\begin{array}{l}-0.024 \\
-0.040\end{array}$ & $\begin{array}{r}-0.048 \\
0.024\end{array}$ \\
\hline $\begin{array}{l}\text { UNCERT } \\
\text { TCE } \\
\text { COMPLEX }\end{array}$ & $\begin{array}{l}-0.121^{*} \\
-0.061\end{array}$ & $\begin{array}{l}0.242^{* *} \\
0.304 \\
0.007\end{array}$ & \begin{tabular}{l}
$-0.157^{* * *}$ \\
\hdashline-0.028
\end{tabular} & $\begin{array}{l}0.275^{* * *} \\
0.116 \\
-0.020\end{array}$ \\
\hline $\begin{array}{l}\text { SUGGEST } \\
\text { HELP } \\
\text { PASS }\end{array}$ & $\begin{array}{l}0.045 \\
0.123^{*} \\
0.141^{* *}\end{array}$ & $\begin{array}{l}-0.192^{* * *} \\
-0.226^{* * *} \\
0.061\end{array}$ & $\begin{array}{c}0.091^{*} \\
-0.065 \\
0.073\end{array}$ & $\begin{array}{l}-0.159 * * * \\
-0.020 \\
-0.035\end{array}$ \\
\hline $\begin{array}{l}\text { USJAP } \\
\text { JAPUS } \\
\text { JAPJAPU } \\
\text { JAPJAPJ }\end{array}$ & \begin{tabular}{c}
$\cdots--$ \\
\hdashline.-- \\
----
\end{tabular} & $\begin{array}{c}\cdots-- \\
\cdots- \\
-\cdots \\
-\cdots\end{array}$ & $\begin{array}{l}0.022 \\
0.041 \\
0.078 \dagger \\
\cdots-\end{array}$ & $\begin{array}{l}-0.059 \\
-0.012 \\
-0.059 \\
---\end{array}$ \\
\hline $\begin{array}{l}\text { GM } \\
\text { TOYOTAJ }\end{array}$ & 0.067 & -0.062 & $\begin{array}{l}-0.111^{*} \\
--.\end{array}$ & \begin{tabular}{l}
$0.184^{* * *}$ \\
\hdashline--
\end{tabular} \\
\hline $\begin{array}{l}\text { Adjusted R2 } \\
\mathrm{N}\end{array}$ & $\begin{array}{l}0.13 \\
348\end{array}$ & $\begin{array}{l}0.26 \\
348\end{array}$ & $\begin{array}{l}0.08 \\
498\end{array}$ & $\begin{array}{l}0.26 \\
502\end{array}$ \\
\hline
\end{tabular}

